International Journal of Instruction e-ISSN: 1308-1470 • www.e-iji.net
OnlineFirst: 17/08/2021

\title{
Federalism and Switzerland as a Federal State
}

\section{Dear Readers,}

A federation is a political union formed by governments (state, province, canton) voluntarily. According to the agreement between them, they are autonomous in their internal affairs and are seen as a single political force against the outside. Federalism is a political system based on the distribution of power between the central authority and the federated authorities. Federalism is a political structure for freedom based on territorial division, is a culture shared by citizens and institutions.

The pillar of the Swiss government system; rule of law, democracy, the social state and federalism. In Switzerland, the federal system is based on the 1848 Federal Constitution. There are 26 cantons, these are considered as states and the cantons are largely autonomous. Unless the Federal Constitution or federal law provides otherwise, federal duties are carried out, executed by the cantons. The building blocks of the Swiss federal state are neither various state theories nor a theoretical system shaped by constitutional law experts. Swiss Federalism is the product of two centuries of development evolution from small independent states to a single modern state. Switzerland, with its long tradition as a federalist state that has successfully redistributed power, has a wealth of experience to offer other countries (Unifer, 2021).

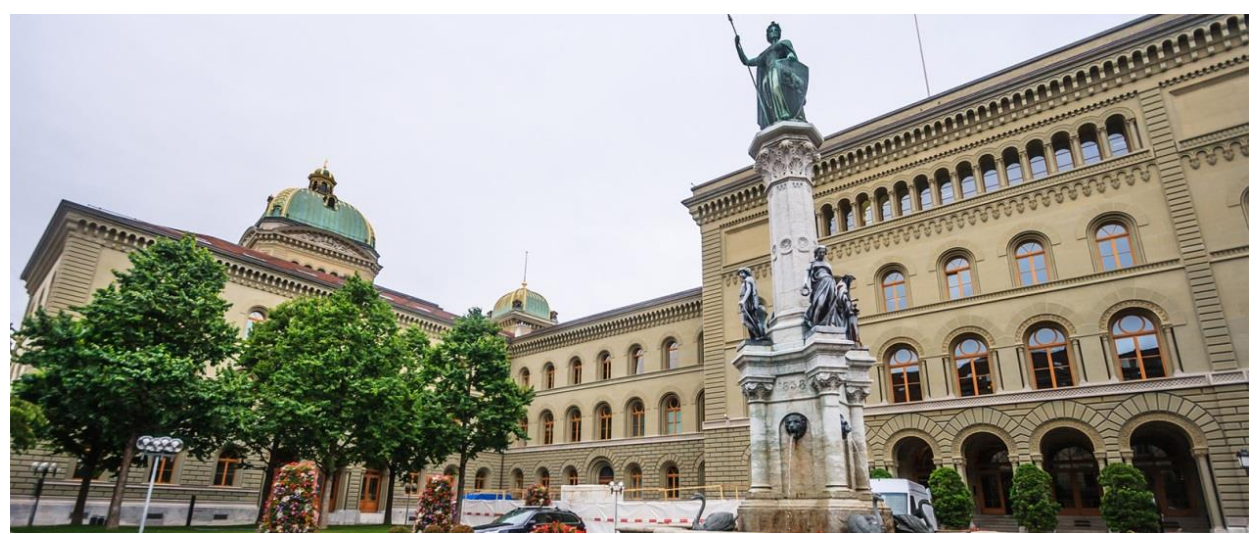

Figure 1

Swiss Federalism (Unifer, 2021a)

Citation: Ari, A. \& Heiter, Y. (2021). Federalism and Switzerland as a Federal State. International Journal of Instruction, 14(4), i-iv. https://doi.org/10.29333/iji.2021.1440a 
Every three to four years, the National Conference on Federalism brings together experts and practitioners from politics, business and public administration to examine Switzerland's unique system of government. Current challenges in the distribution of power between the federal government, cantons, municipalities and institutions are discussed. The conference aims to specify the requirements for federalism with a view to social changes and to consolidate the interaction. The National Conference on Federalism 2021 was dedicated to the topic of «Federalism and Dynamics» and took place on May 27/28 in the host canton of Basel-Stadt and due to the pandemic, the 2021 National Federalism Conference was held virtually (Foederalismus 2021).

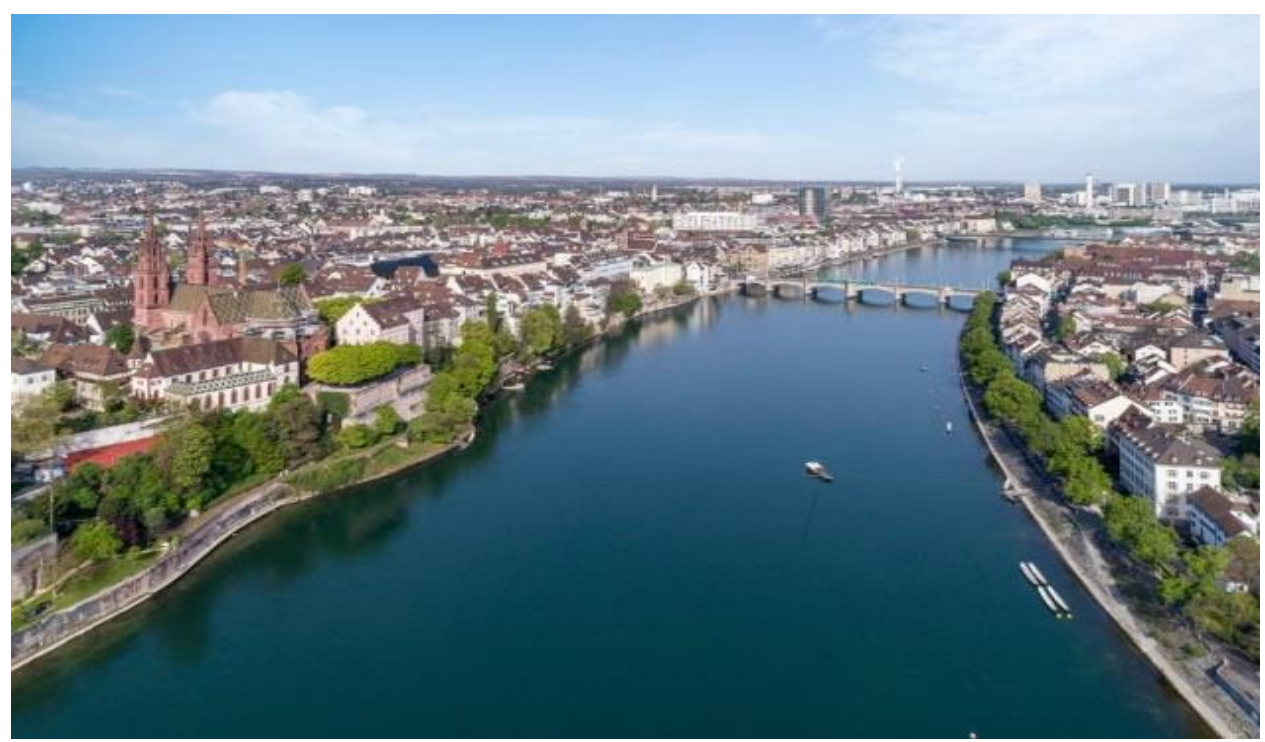

Figure 2

National Conference on Federalism 2021, Basel (Foederalismus 2021)

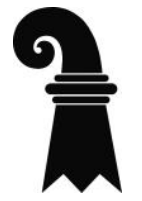

Federalism, like direct democracy, is an integral part of Switzerland. It makes them strong and ensures rich economic, social and cultural diversity for the country and its inhabitants. Its core functions are that the tasks of the state are divided between the three levels (federal government, cantons as well as cities and municipalities) to find solutions that meet needs. This increases innovation and competitiveness and at the same time protects minorities, be it in terms of language, culture, religion or special geographic-topographical conditions. In this way, federalism promotes understanding and internal cohesion in Switzerland (Erklärung von Basel 2021).

The Institute of Federalism is attached to the University of Fribourg and directed in collaboration with the $\mathrm{CH}$ Foundation for Federal Cooperation. Since its establishment in 1984, the Institute of Federalism has dealt with issues of federalism, decentralization, state organization, rule of law, democracy and human rights. The Institute is receiving 
an increasing number of mandates to perform consulting, training and continuing education in this area. The international component of the Institute acquired such great importance, that since 1997, there has been a separate section dedicated to international cooperation and comparative federalist research. This international section is called IRCC, International Research and Consulting Centre. Both the national and the international sections at the Institute continue to work closely together (Unifer, 2021b).

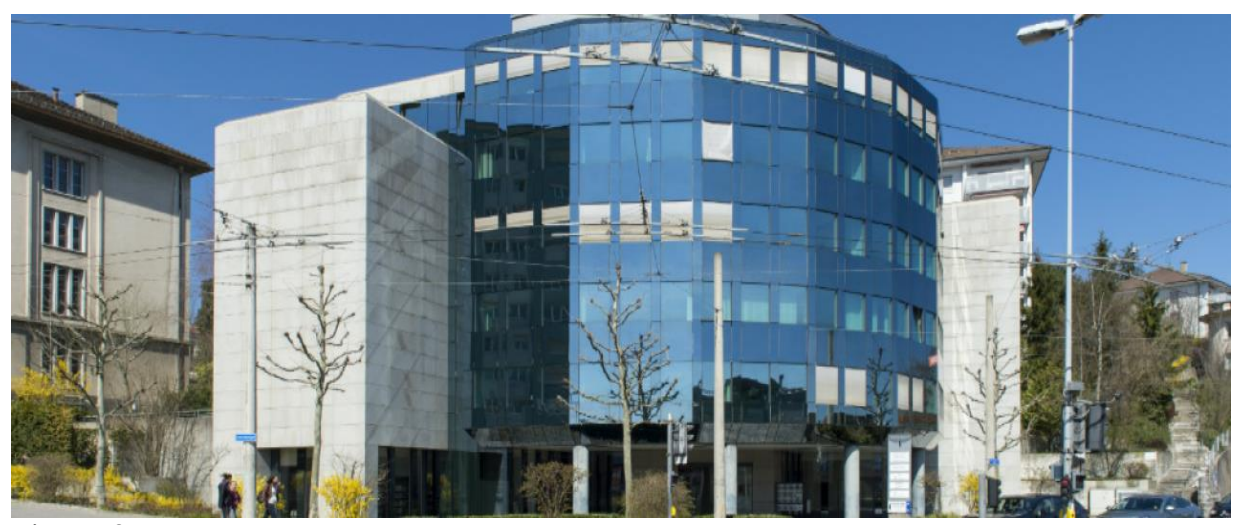

Figure 3

Institute of Federalism (https://www.unifr.ch/federalism/en/)

Through research, services and training offers, the Institute contributes in an academically sound and practical manner to specify and further develop the principles of good governance. The Institute's activities focus on the following areas (Unifer, 2021c):

- General theory of federal and decentralized state organisation

- Fundamentals and further development of the Swiss federal state

- Comparative federalism

- Democracy

- Fundamental and human rights

- Protection of minorities

- Conflict prevention and management

- Legisprudence

- Administrative law

- Public procedural law

The democracy culture of Switzerland is a result of its own institutions and system of education. There is much to learn from these institutions like the Institute of Federalism.

Sincerely,

Prof. Asim Ari

Editor in Chief

Visiting Researcher/Lecturer at the Institute of Institute of Federalism

Federalism, University of Fribourg, Switzerland University of Fribourg, Switzerland 
Email: asimari64@gmail.com

Website: http://www.federalism.ch
Email: yvonne.heiter-steiner@unifr.ch

Website: http://www.federalism.ch

\section{REFERENCES}

Ari, A. (2019). The Institute of Federalism, in Fribourg. International Journal of Instruction, 12(2), i-ii. http://www.e-iji.net/dosyalar/iji_2019_2_0.pdf

Ari, A. \& Heiter, Y. (2020). It is a privilege to study at University of Fribourg. International Journal of Instruction, 13(4), i-iv. http://www.eiji.net/dosyalar/iji_2020_4_0.pdf

Ari, A. \& Schmitt, N. (2021). Democracy Education in Switzerland, Known for its Strong Democracy. International Journal of Instruction, 14(3), i-iv. https://doi.org/10.29333/iji.2021.1430a

Ari, A. \& Stöckli, A. (2021). Switzerland Case as an Example of Success in Multicultural Education: From the Editor. International Journal of Instruction, 14(2), iiii. https://doi.org/10.29333/iji.2021.1420a.

Erklärung von Basel 2021 (2021). Gemeinsames Engagement für einen zukunftsgerichteten Föderalismus (Joint commitment to a future-oriented federalism). Retrieved from: https://www.foederalismus2021.bs.ch/erklaerung-von-basel.html (Retrieved July 18, 2021).

Foederalismus (2021). National Conference on Federalism 2021. Retrieved from: https://www.foederalismus2021.bs.ch/ (Retrieved July 18, 2021).

Heiter, Y. \& Ari, A. (2020). Summer University on Federalism, Decentralisation and Conflict Resolution. . International Journal of Instruction, 13(2), i-iii. http://www.eiji.net/dosyalar/iji_2020_2_0.pdf

Unifer (2021a). Swiss Federalism. Retrieved from: https://www.unifr.ch/federalism/en/topics/chfederalism.html (Retrieved July 18, 2021).

Unifer (2021b). Comparative Federalism. Retrieved from: https://www.unifr.ch/federalism/en/topics/comparativefed.html (Retrieved July 18, 2021).

Unifer (2021c). The Institute. Retrieved from: https://www.unifr.ch/federalism/en/institute/profile.html (Retrieved July 18, 2021). 